\title{
PROTOPLASMATOLOGIA
}

\section{HANDBUCH DER PROTOPLASMAFORSCHUNG}

\author{
BEGRÜNDET VON \\ L. V. HEILBRUNN $\cdot \underset{\text { PHILADELPHIA }}{\text { F. WEBER }}$
}

HERAUSGEGEBEN VON
M. ALFERT - H. BAUER - C. V. HARDING - W. SANDRITTER · P. SITTE BERKELEY
TÜBINGEN
ROCHESTER
GIESSEN
HEIDELBERG

MITHERAUSGEBER

W. H. ARISZ-GRONINGEN - J. BRACHET-BRUXELLES - H. G. CALLAN-ST. ANDREWS

R. COLLANDER-HELSINKI - K. DAN-TOKYO - E. FAURÉ-FREMIET-PARIS

A. FREY-WYSSLING -ZURICH - L. GEITLER-WIEN • K. HÖFLER-WIEN

M. H. JACOBS-PHILADELPHIA - N. KAMIYA-OSAKA - W. MENKE-KÖLN

A. MONROY-PALERMO - A. PISCHINGER-WIEN • J. RUNNSTROM-STOCKHOLM

\author{
BAND VI \\ KERN- UND ZELLTEILUNG
}

G

DER KERNTEILUNGSMECHANISMUS

1

THE BEHAVIOR OF CENTRIOLES AND THE STRUCTURE AND FORMATION OF THE ACHROMATIC FIGURE

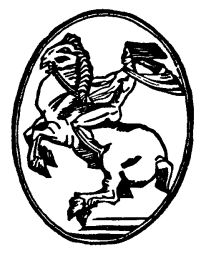

1966

SPRINGER-VERLAG

WIEN ・ NEW YORK 


\section{THE BEHAVIOR OF CENTRIOLES AND THE STRUCTURE AND FORMATION OF THE ACHROMATIC FIGURE}

\section{HANS A. WENT \\ PULLMAN}

WITH 30 FIGURES

1966

SPR INGER-VERLAG

WIEN • NEW YORK 
ISBN-13: $978-3-211-80783-5 \quad$ e-ISBN-13: $978-3-7091-5571-4$
DOI: $10.1007 / 978-3-7091-5571-4$

ALLE RECHTE, INSBESONDERE DAS DER ÜBERSETZUNG

IN FREMDE SPRACHEN, VORBEHALTEN.

OHNE SCHRIFTLICHE GENEHMIGUNG DES VERLAGES IST ES AUCH NICHT GESTATTET, DIESES BUCH ODER TEILE DARA US AUF PHOTOMECHANISCHEM WEGE (PHOTOKOPIE, MIKROKOPIE) ODER SONSTWIE ZU VERVIELFALTIGEN.

(C) 1966 BY SPRINGER-VERLAG/WIEN

LIBRARY OF CONGRESS CATALOG CARD NUMBER: 55-880

Softcover reprint of the hardcover 1st edition 1966 